\title{
Early termination of vocational training: dropout or stopout?
}

\author{
Gabriele Wydra-Somaggio* (1)
}

\section{*Correspondence:}

gabriele.

wydra-somaggio2@iab.de

Institute for Employment

Research (IAB),

Eschbergerweg 68,

66121 Saarbruecken,

Germany

\begin{abstract}
Dropping out of the educational system has marked negative consequences in the labour market. Dropping out is followed by an early termination that does not necessarily mean leaving the educational system without graduating. Trainees may reassess their initial choice by starting another vocational education and training (VET) programme and preserve their labour market chances when graduating. This paper examines the factors that drive the decision to stop out (start new vocational training) after an early termination. The analysis is based on a data set for VET in Germany (Ausbildungspanel Saarland) that contains detailed information on the VET careers and labour market outcomes of almost 3000 apprentices who terminated their education early. The results show that approximately 71 percent of apprentices continue with another VET programme after a termination. Termination at an early stage of VET and training in a small establishment are more likely to lead to stopping out than to dropping out. Stopouts who terminate their contracts during an early stage of their VET programme are more likely to change their occupation and obtain a formal VET degree. The results suggest that dissatisfaction with VET must be recognized at an early stage in order for students to take appropriate measures with the aim of graduation.
\end{abstract}

Keywords: Vocational education, Timing of early termination, Dropout, Stopout

\section{Background}

In many countries, formal educational degrees are necessary to pursue a stable career (e.g., Campolieti et al. 2010). Dropping out of education means leaving the educational system with no formal degree. This may be associated with negative labour market consequences, such as a discontinuous labour market career, unemployment, holding an unskilled jobs and low wages (e.g., Oreopoulos 2007; Gesthuizen and Solga 2014; Patzina and Wydra-Somaggio 2020). However, students who revise their initial dropout decision may continue their education in another occupational field and obtain a formal vocational degree. They then preserve their chances of successfully integrating into the labour market. Changing one's initial educational decision is rather common. For example, in Germany, approximately every fourth apprentice terminates his or her vocational education and training (VET) (BIBB 2019), but only a small share are permanent dropouts, as Kotte (2018) shows. A vast set of studies have found manifold reasons for dropping out from the educational system (Stratton et al. 2008, Montmarquette et al.

(c) The Author(s) 2021. This article is licensed under a Creative Commons Attribution 4.0 International License, which permits use, sharing, adaptation, distribution and reproduction in any medium or format, as long as you give appropriate credit to the original author(s) and the source, provide a link to the Creative Commons licence, and indicate if changes were made. The images or other third party material in this article are included in the article's Creative Commons licence, unless indicated otherwise in a credit line to the material. If material is not included in the article's Creative Commons licence and your intended use is not permitted by statutory regulation or exceeds the permitted use, you will need to obtain permission directly from the copyright holder. To view a copy of this licence, visit http://creativeco mmons.org/licenses/by/4.0/. 
2001, Lassibille and Navarro Gomes 2008, Eckstein and Wolpin 1999, Kearney and Levine 2014, Coneus et al. 2011, for example). For example, there are studies that show that timing is a decisive factor in the decision to drop out (Gury 2011; Mangan and Trendle 2008). Other studies consider factors such as training conditions in the establishment (Karmel and Mlotkowski 2010) or personal characteristics of the student such as education, family background and social conditions (Aarkrog et al. 2018; Bishop and Mane 2001; Glaesser 2006). The effects of cognitive ability and personality traits (Eegdeman et al. 2018, Volodina 2015), school degrees (Laporte 2013) and adequate prior knowledge (Gubbels et al. 2019) are the subjects of additional studies. Other work has investigated the consequences of dropping out for a person's future employment trajectory (Rumberger and Lamb 2003; Campolieti et al. 2010; Bradley and Lenton 2007; Oreopoulos 2007, for example). Although a vast set of studies examines the effects of dropping out, the literature on the decision process between succeeding in education and dropping out is rather scant (Cerda-Navarro et al. 2017). Laporte et al. (2013), for example, distinguish the outcomes from completing vocational training, continuing another apprenticeship and discontinuing training or dropping out.

Hence, the question of who continues with VET after an early termination (stopout) and who drop out arises. Dropping out also be possible if a new VET is early terminated again. Thus, a further question of who succeeds in their second-choice VET programme arises. This paper aims to identify the factors behind dropout-stopout decisions. I focus on the time spent in VET and the relation to the likelihood of continuing VET in a different occupational field. To do this, I distinguish between termination at an early stage (within the first year of training) and at a late stage (within the last year of training). The contribution of this paper, firstly, is to reveal more information about the factors explaining the dropout-stopout decision, which requires the consideration of two possible decision paths. Students can leave the educational system directly after the first early termination (dropout) or they can begin another training programme (stopout) and drop out in a second early termination. Second, I analyse the dropout-stopout decision within a standardized training framework focusing on the German VET system, which is the most common way to obtain a post-secondary vocational degree in Germany. Third, I use unique process data from the Saarland Apprenticeship Panel (Ausbildungspanel Saarland) covering crucial VET characteristics that allow for the identification of dropout and stopout students.

The structure of the paper is as follows: Section "Theoretical background and previous research" provides an initial overview of the literature combined with the theoretical background. Section "Data and method" introduces the data, the variables and the methodology. Section "Results" provides a description of the institutional context of the VET system and introduces the data. Section "Discussion" reveals the empirical evidence. A discussion follows in Section "Discussion". Then, I conclude.

\section{Theoretical background and previous research}

According to the theory of Becker (1962), individuals decide to invest in training when the monetary returns exceed the costs. Revising an educational decision is not possible, because individuals are aware of all information at all times. Manski (1989) and Montmarquette (2001) overcome this strict assumption of Becker (1962) by describing 
training as an experiment in which a continuous re-evaluation of the educational decision occurs. To do this, students have to begin training and gather information to judge whether they can manage the vocational training in a given training environment. The analysis of Aarkrog et al. (2018) is based on such a re-evaluation process and the authors argue that a student continuously revises his or her initial educational decision taking changes in personal circumstances into account. Thus, students are able to detect discrepancies between their initial expectations and actual training circumstances, such as educational and occupational requirements and context (Karmel and Mlotkowski 2010; Snell and Hart 2008). Based on the information gained, students can decide whether the vocational training programme is what they envisaged and thus are able to repeatedly reassess their initial decision (e.g., Mangan and Trendle 2008; Biewen and Tapalaga 2017). Moreover, this reassessment becomes more substantial the longer the student's tenure in the training programme continues, as it is based on a greater amount of valid information on the training conditions. This reassessment might result in early termination.

Hence, revising the initial educational decision depends on the investments made so far. Investments increase with time in training, and the (opportunity) costs of termination are higher at a later stage of training (see also Hodgson 2007), as the human capital investment is higher, which could result in higher productivity and thus in higher wages. Individuals who terminate their training at a later stage forgo the potentially higher wages that they may have earned if they had completed their vocational training. Furthermore, earnings might also be higher in establishments that intensively invest in training and thus provide good training conditions in order to retain apprentices after training.

The overall costs and the loss of the related returns of an early termination decision are therefore higher at a later stage of training, although the costs of subsequent training remain the same. Hence, early termination at a later stage should result in dropping out rather than stopping out. The costs of undertaking new training, however, decrease if the new training is in the same occupational field because the human capital acquired so far can be applied to that new programme. Furthermore, an occupational change is less likely to occur the later the timing of the termination is. Finally, individuals who terminate earlier should be more likely to successfully graduate from their subsequent training programme if this training is in the same initial occupational field instead of a different occupational field. However, stopping out of education can still ultimately lead to dropping out of education if the subsequent vocational training is not successfully completed.

Following the presented theoretical relations, Germeijs and Verschueren (2007) investigate the influence of the educational decisions after schooling on choices of higher education. They differentiate among the outcomes of committing, failing and stopping out and show that these outcomes are explained by, e.g., the number of educational alternatives or training frameworks considered before the start of higher education.

Only a few studies differentiate between dropping out of education and interrupting educational investment while taking the timing of termination into account. Laporte et al. (2013) show that the longer apprentices participate in an apprenticeship, the more likely they are to drop out of the apprenticeship. Mangan and Trendle (2008) and Gury 
(2011) examine the changes over time in the impact of different factors on training decisions in Australia and France, respectively. Mangan and Trendle (2008) ascribe a significant role to timing with regard to dropping out and stopping out. Gury (2011) finds that the duration of vocational training mediates the influence of students' education and family situation on dropping out. Educational background is only a significant predictor if dropout decisions are made during the first two years of study. Arulampalam et al. (2001) also confirm the changing impact of education over the amount of time spent in training. They find a decreasing influence of education on exit as the length of time spent in training before dropout occurs increases. These studies show that timing is a rather important explanatory factor for whether a trainee continues with further educational training after an early termination.

Furthermore, several studies have shown that training conditions, such as poor training quality, lack of educational support from the training firm and low training wages, are important explanatory factors (Karmel and Mlotkowsky 2010; Snell and Hart 2008). Rohrbach-Schmid and Uhly (2015) show that occupations, which affect different training conditions, for example, working time, drive the decision to drop out. Finally, most of the studies have identified educational attainment as the main explanatory factor in dropout-stopout decisions. Stratton et al. (2008), who distinguish between dropping out and stopping out, find that the likelihood of dropping out is higher than the likelihood of stopping out if the student's educational level is low. Laporte et al. (2013) show, among others, that having a lower school degree reduces the likelihood of completing training. To date, only one study for Germany has examined the likelihood that a student continues in education after dropping out, but it does not separate apprenticeship dropouts from university dropouts (Glaesser 2006). To close this gap, the dropout-stopout decision is investigated for the VET, which characterizes a standardized training framework.

\section{Data and methods}

\section{Data and sample selection}

The Saarland Apprenticeship Panel combines the Integrated Employment Biographies (IEBs) from the Institute for Employment Research (IAB) with information from the Saarland Chamber of Industry and Commerce (IHK) and Chamber of Trade (HWK) (for more details see Wydra-Somaggio 2015). The panel includes information on all apprentices who participated in a VET programme in establishments in Saarland for at least one day between 1999 and 2002. Information on employment histories covers up until 2012 and includes precise dates regarding time spent in the apprenticeship, employment, labour policy measures, unemployment, and detailed personal characteristics (see Oberschachtsiek et al. 2009). ${ }^{1}$ With this information, I can differentiate between apprenticeship stopouts and dropouts. With the Saarland Apprenticeship Panel, an exact analysis of terminations and further apprenticeship trajectories is possible even if apprentices begin their subsequent apprenticeship several years after the termination of their first apprenticeship.

\footnotetext{
${ }^{1}$ Although the data used only covers one federal state, the findings are representative of the federal states in western Germany, as Saarland's economic structure is now more closely aligned to that of western Germany than to that of eastern Germany due to structural changes. The structure of the apprenticed occupations also corresponds to that of other states in western Germany.
} 
The sample for the analysis contains only individuals who terminated their first VET programme early and were assigned to exactly one chamber. All apprenticeship beginners who were 23 years of age or younger in Saarland were observed. Early termination must have taken place between 1999 and 2002 (for details, see Table 5 in the Appendix). Our analysis encompasses 2896 persons who terminated their first VET programme early.

\section{Variables and methodology}

The main variable of interest is whether an apprentice begins a further VET programme after a termination. To assess the first outcome, it is essential to distinguish between stopping out from dropping out. Information on the end of the VET programme defines the date of early termination. To identify a stopout, IEBs provide supplemental VET information on any second VET that is outside the region to which the chamber belongs. That is why the chamber data may not have information on all subsequent VETs. Identification using the available chamber information would not include all subsequent VETs and thus would lead to biased results. As there is no direct information in the IEBs on successful graduation from a VET programme, I define VET success by changes in occupational position (employed with vocational degree) and VET duration (at least 730 days). Stopouts are individuals who participate in a subsequent VET programme in a different establishment and/or different occupation. As there is a relation between the timing of early termination and changing training occupations upon beginning a new VET programme, I disentangle the outcome variables into starting a new VET programme in the same occupation, starting a new VET programme in another occupation and dropping out.

As discussed in the literature review, one main factor that affects the decision to begin a new apprenticeship is the amount of past investments in training. To capture this, I control for the length of time over which investments in training take place. Given the information available in the data set, the time between the beginning and the end of the VET programme covers the length of training. I create a categorical variable with the following categories: (a) termination during the trial period (first four months of the VET programme), (b) termination in the first year of the VET programme outside the trial period (first five to 12 months), (c) termination in the second year of the VET programme, and (d) termination in the third/fourth year of the VET programme.

The amount of training wages are on the one hand dependent on time spent in training. On the other hand, they reflect training conditions as establishments can pay a bonus for more engaged apprentices, although wages are subject to bargaining by unions (see Mohrenweiser et al. 2020). These higher wages point to the higher productivity of apprentices, which might be due to higher training investments by the establishments and better training conditions. As the dummy variable contains wages at early termination, which are above the average daily wage for a given training year and training occupation, earnings captures training conditions rather than training investment. Second, I further capture training conditions through establishment characteristics, as VET takes place in training establishments, which affects the success of VET and the decision to drop out or stop out (see Karmel and Mlotkowski 2010). Apprentices in smaller establishments are more likely to terminate early (Rohrbach-Schmidt and Uhly 2015). This is 


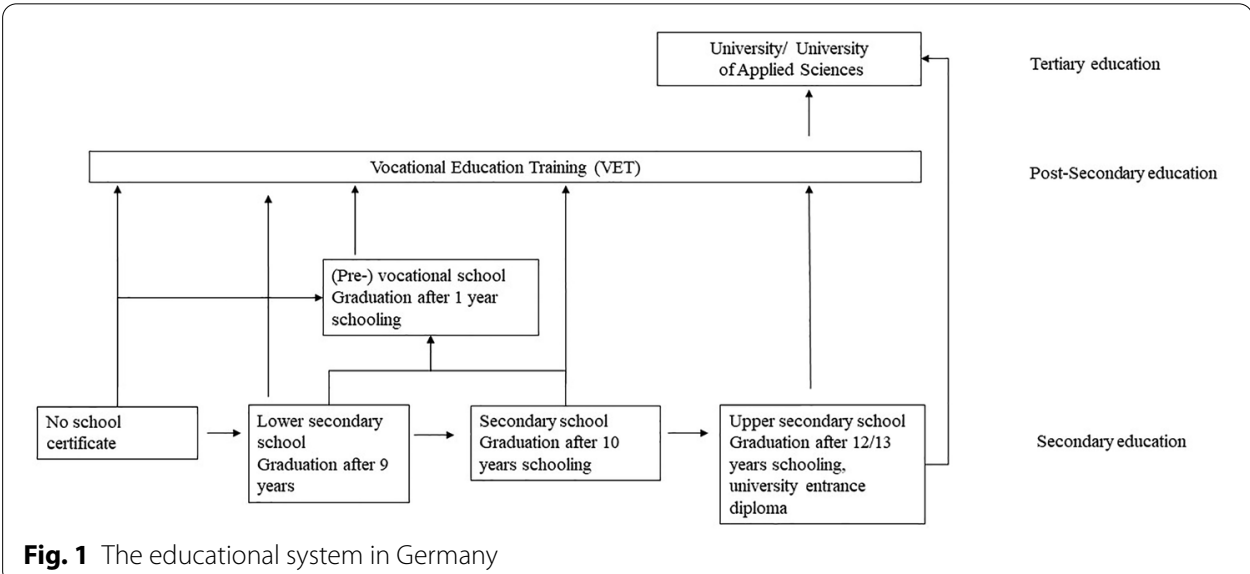

due to small establishments having fewer resources than large establishments. Furthermore, I control for economic sector. Changes in training firm conditions combine firm size and the training wages of both the first and second VET programme. I distinguish between change into larger establishments with lower (higher) wages and smaller establishment with lower (higher) wages. This variable is included in the estimation of probability of succeeding in the second VET programme.

Rohrbach-Schmidt and Uhly (2015) show that the characteristics of the training occupation, rather than the personal characteristics of apprentices, explain the decision to terminate an apprenticeship. To take these differences in training occupations into account, I generate the share of early terminations in a given training occupation. This share may also capture training conditions with respect to the training occupation. For example, the early termination rate in the occupation of cook is rather high due, in addition to poor working conditions, to the rather low level of qualifications among apprentices. Therefore, in a given training occupation, the share of individuals who terminate early might capture characteristics of the training occupation that might in turn affect the dropout-stopout decision.

The apprenticeship system offers training for 2, 3, or 3.5 years, which also means different requirements for apprentices. When compared to occupations with a three-year VET programme, occupations with a two-year VET programme require fewer skills and less learning. The formal length of training varies among occupations, which approximates differences in the qualification requirements. Finally, I control for occupational change between the first and second VET programme at the 3-digit occupation level.

According to previous studies, schooling is one of the main explanatory factors for dropout-stopout- decisions, which might depend on educational opportunities after early termination. In Germany, every school leaver with or without a formal school certificate can attend a VET programme. Whereas the educational opportunities of apprentices with a secondary school leaving certificate or below are restricted to obtaining a vocational degree in the upper post-secondary educational (e.g., VET) system after early termination, apprentices with a higher school leaving certificate may attend university and obtain a tertiary degree as well (see Fig. 1 in Appendix). Apprentices have to apply for a VET programme with an establishment. This might increase the fit between the apprentice and training establishment, as employers choose the applicants who best 
meet their training requirements. I expect that apprentices with both lower and higher qualifications are more likely to drop out of VET than to interrupt it after a contract termination; thus, school qualification matters for whether a trainee becomes a stopout or a dropout. I differentiate between no school leaving certificate, lower secondary school, pre-vocational school, vocational school, secondary school, upper secondary school and others.

A female dummy captures gender-specific selection in training occupations and in the likelihood of terminating early, which varies across occupations. Furthermore, age might also affect the dropout-stopout decision. Older apprentices may decide to drop out and enter the labour market rather than begin a new VET programme. As the age range of trainees is not very large, a dummy captures apprentices who are older than 20 years. Finally, I control for German nationality as well as the year when the apprenticeship starts to capture economic conditions.

First, I estimate a binary log model with robust standard errors. As there may be correlations among individuals in the same training occupation and training establishment due to establishment- and occupation-specific features such as working times or training conditions that cannot be observed, I cluster these variables by training cells. A training cell contains individuals in the same occupation and the same establishment. Furthermore, I restrict the sample to individuals who are in training occupations with a rate of termination of less than 50 percent. This restriction takes possible differences in the reason for termination into account. When less than half of apprentices terminate early, individual characteristics should matter more than apprenticeship conditions. A multinomial logit model allows for estimation of the likelihood of each of the disentangled outcomes, dividing the stopouts into stopouts with and without a second VET programme in their initial occupation. I use these results to correct the logit model used to estimate the coefficients affecting success in the subsequent VET. This is necessary because stopouts with no school-leaving certificate or a low-level certificate are overrepresented in the sample but are usually less likely to continue after a termination. ${ }^{2}$

\section{Results}

\section{Descriptive statistics}

Table 1 shows the descriptive differences between stopouts and dropouts in our sample. Approximately 70.5 percent of apprentices who terminate their apprenticeship early continue with another VET. Stopouts are more likely than dropouts to terminate their VET at an early stage (25.7 percent of the stopouts compared to 21.5 percent of the dropouts). Only 11.9 percent of stopouts terminate during the last year, whereas 18.5 percent of dropouts do so. 60.6 percent of stopouts change their training occupation. The share of job changes is higher for early stopouts than for late stopouts. The share of stopouts is higher than that of dropouts among those terminating their VET in a small establishment ( 45.2 percent vs. 36.7 percent), whereas apprentices in a large establishment are more likely to drop out than stop out of the VET system after termination (13.7 percent vs. 70.0 percent). Dropouts earn less than stopouts. The share of

\footnotetext{
${ }^{2}$ For the Heckman correction, I apply the Mills ratio. I estimate the inverse probability by considering the characteristics of the first VET programme except for the length of time in training for each type of school-leaving certificate.
} 
Table 1 Descriptive statistics of stopouts and dropouts

\begin{tabular}{|c|c|c|c|}
\hline Variables & Stopouts & Dropouts & $t$-test \\
\hline Share of all early termination & 70.5 & & \\
\hline Success in second apprenticeship & 54.5 & & \\
\hline \multicolumn{4}{|c|}{ Timing of premature apprenticeship contract termination } \\
\hline Trial period & 25.7 & 21.5 & 1.17 \\
\hline First year of apprenticeship & 32.7 & 29.2 & 0.92 \\
\hline Second year of apprenticeship & 29.7 & 30.8 & -0.31 \\
\hline Third/Fourth year of apprenticeship & 11.9 & 18.5 & -1.95 \\
\hline Occupational change & 60.6 & & \\
\hline \multicolumn{4}{|l|}{ Training conditions } \\
\hline \multicolumn{4}{|l|}{ Establishment size } \\
\hline Less than 10 employees & 45.2 & 36.7 & 2.21 \\
\hline Between 50 and 249 employees & 31.9 & 26.8 & 1.33 \\
\hline Between 10 and 49 employees & 15.9 & 22.8 & -1.96 \\
\hline More than 250 employees & 7.0 & 13.7 & -2.17 \\
\hline Log of apprenticeship earnings & 39.6 & 34.2 & 1.39 \\
\hline Daily wage at time of premature termination $(€)$ & 13.9 & 13.8 & 0.5 \\
\hline \multicolumn{4}{|l|}{ Duration of apprenticeship for occupation } \\
\hline 3 years & 68.3 & 70.0 & -0.45 \\
\hline 3.5 years & 31.7 & 30.0 & 0.45 \\
\hline Share of early terminations by occupation & 49.2 & 47.7 & 5.73 \\
\hline \multicolumn{4}{|l|}{ Schooling } \\
\hline No certificate & 4.8 & 10.1 & -1.76 \\
\hline Lower secondary school leaving certificate & 60.4 & 54.6 & 1.45 \\
\hline Pre-vocational school leaving certificate & 2.7 & 4.6 & -0.79 \\
\hline Vocational school leaving certificate & 1.1 & 1.6 & -0.27 \\
\hline Secondary school leaving certificate & 24.7 & 17.8 & 1.92 \\
\hline Higher school leaving certificate & 5.5 & 10.3 & -1.62 \\
\hline Others & 0.8 & 1.0 & -0.16 \\
\hline \multicolumn{4}{|l|}{ Individual characteristics } \\
\hline Age at premature termination & 18.4 & 19.2 & -10.6 \\
\hline Female & 34.7 & 38.0 & -0.84 \\
\hline German nationality & 96.6 & 93.0 & 1.37 \\
\hline \multicolumn{4}{|l|}{ Start of apprenticeship } \\
\hline 1999 & 27.3 & 26.1 & 0.28 \\
\hline 2000 & 27.2 & 26.6 & 0.16 \\
\hline 2001 & 25.3 & 23.7 & 0.45 \\
\hline 2002 & 20.2 & 23.6 & -0.92 \\
\hline Observations & 2043 & 853 & 2896 \\
\hline
\end{tabular}

Source: Saarland Apprenticeship Panel. author's own calculations

dropouts with no school-leaving certificate or a higher certificate is higher than that of stopouts. Stopouts are on average 18.4 years old and almost one year older than dropouts. The share of women who begin another VET training is slightly lower than the share of women who drop out.

\section{Drop out or stop out?}

Three models explore the relationship between early termination and the likelihood of continuing VET in another study field-in other words, of being a stopout. Table 2 
Table 2 Logit model for the probability of undertaking a new VET programme after early termination (marginal effects)

Base model Training cell clusters Training cell clusters with low early termination rates

Time of termination

Trial period (reference)

First year ${ }^{1}$

$-0.012$

$-0.015$

0.003

Second year

$(-0.55)$

$(-0.68)$

(0.10)

$-0.046^{* *}$

$-0.049^{* *}$

$-0.056^{*}$

Third/Fourth year

$(-2.02)$

$(-2.20)$

$(-1.82)$

$-0.113^{* * *}$

$-0.120^{* * *}$

$-0.118^{* * *}$

Training conditions

$(-4.95)$

$(-4.09)$

$(-2.82)$

Log of VET earnings

0.018

0.028

$-0.008$

(1.00)

(1.54)

$(-0.33)$

Establishment size

More than 250 employees (reference)

Less than 10 employees

$0.113^{* * *}$

(3.13)

Between 10 and 49 employees

$0.118^{* * *}$

(3.28)

Between 50 and 249 employees

$0.077^{* *}$

(2.21)

Industry

Yes

Duration of apprenticeship for occupation

3.5 years (reference)

0.007

0.013

0.015

(0.31)

(0.63)

(0.51)

Share of early terminations by occupation

$-0.001$

0.001

$(-1.80)$

(0.64)

Schooling

No certificate (reference)

Lower secondary school leaving certificate

$0.130^{* * *}$

$0.169^{* * *}$

$0.186^{* * *}$

Pre-vocational school leaving certificate

0.020

(5.30)

(4.57)

(0.38)

0.038

0.040

0.091

(0.73)

(0.50)

Vocational school leaving certificate

(1.17)

$0.125^{*}$

0.144

Secondary school leaving certificate

$0.197^{* * *}$

(1.67)

(1.50)

(5.22)

$0.243^{* * *}$

$0.252^{* * *}$

$0.090^{*}$

(6.49)

(5.03)

Higher school leaving certificate

(1.80)

$0.116^{* *}$

$0.147^{* *}$

Others

0.118

(2.48)

(2.46)

(1.40)

.116

0.059

Individual characteristics

Female

$-0.04^{*}$

$-0.31$

(0.43)

German nationality

$(-1.53)$

$-0.023$

$0.136^{* * *}$

$0.133^{* * *}$

$(-0-85)$

(3.62)

(3.44)

$0.192^{* * *}$

$-0.102^{* * *}$

$-0.115^{* * *}$

(3.31)

Over 20 years at time of termination

$$
(-4.56)
$$

$(-5.38)$

$-0.070^{* *}$

$(-2.42)$ 
Table 2 (continued)

\begin{tabular}{llll}
\hline & Base model & Training cell clusters & $\begin{array}{l}\text { Training cell clusters } \\
\text { with low early termination } \\
\text { rates }\end{array}$ \\
\hline $\begin{array}{l}\text { Start of VET } \\
1999 \text { (reference) }\end{array}$ & & & \\
2000 & -0.027 & -0.015 & -0.000 \\
& $(-1.21)$ & $(-0.65)$ & $(-0.01)$ \\
2001 & -0.028 & -0.019 & -0.021 \\
2002 & $(-1.20)$ & $(-0.84)$ & $(-0.64)$ \\
& $-0.067^{* *}$ & $-0.058^{* *}$ & 0.057 \\
N & $(-2.83)$ & $(-2.34)$ & $(-1.65)$ \\
Pseudo-R2 & 2896 & 2896 & 1537 \\
\hline
\end{tabular}

Source: Saarland Apprenticeship Panel; author's calculations

${ }^{*} p<0.10 .{ }^{* *} p<0.05$. ${ }^{* *} p<0.01 .{ }^{1}$ Between 5 and 12 months after the start of VET

shows the base logit model with robust standard errors (column 2) and the logit model with training cell clusters to identify homogenous training conditions and take differences between apprentices into account (column 3). The model in column 4 restricts the sample from the model in column 3 to those whose first training occupation has a low early termination rate.

The logit regressions in Table 2 show that the timing of termination has a significant effect on starting a new apprenticeship. The likelihood of stopping out decreases the later the timing of the termination is.

Obviously, there is no difference in the effects of terminating during the trial period or during the second half of the first year of the VET programme on starting a later VET programme. In contrast, the marginal effect of a termination during the second year of VET is -0.046 (see column 2), implying that the probability of a subsequent VET programme being started by those who terminate in the second year of their initial VET programme is approximately 4.6 percentage points lower than that of those who terminate during the trial period. The probability of starting another VET programme after early termination during the final year is approximately 11.3 percentage points lower than the probability of doing so after early termination during the trial period. In the models with training cell clusters and a restricted sample, the effects are similar (columns 3 and 4). The later the termination occurs, the stronger the correlation becomes.

The role of training conditions is ambiguous. Earning an above-average wage during the first VET programme has no significant influence on the probability of starting a subsequent VET programme after early termination. Terminating an apprenticeship early in a very small or small establishment raises the likelihood of beginning another VET programme. A high early termination rate within an occupation or within occupations that have a regular VET duration of three years has no significant effect on the dropout-stopout decision.

However, there is a significant relation between the level of schooling and beginning a new VET programme. Those with a lower secondary or a secondary school leaving certificate remain in the VET system with a likelihood that is 13.0 or 19.7 percentage points higher than the likelihood of those without any school-leaving certificate. The marginal 
effect of being a stopout is only 9.0 percentage points higher among those with a higher schooling certificate that also allows them to pursue academic training than among those without any certificate.

The multinomial logit model in Table 3 distinguishes between the effects on the outcome variables of dropouts and of stopouts with and without occupational changes. The results suggest that the timing of contract termination has a significant effect on both dropping out and stopping out without any change in occupation: the likelihood of dropping out increases with the amount of time spent in the first VET programme. This relation also holds for stopping out without any occupational change between the first and subsequent VET programme. The later the termination is, the higher the likelihood of dropping out (see column 2) or of stopping out without any occupational change (column 3) is. The marginal effects, however, are negative for stopouts who change occupations. Starting a VET in another training occupation is less likely among those who terminate at a later stage of the VET programme. ${ }^{3}$ These estimations are robust to the model that clusters on the training cells (column 5 to column 7) and to the model with the restricted sample (column 6 to column 9). The results show that training conditions have significant effects. Early termination in establishments with fewer than 250 employees reduces the likelihood of dropping out. Apprentices who terminate their VET early when their programme has a regular duration of 3 years maximum are more likely to stop out with an occupational change. Moreover, apprentices in a training occupation with a high rate of early termination are more likely to begin VET in another field of study. The differences in the effect of school leaving certificates are only significant between those who drop out and those who stop out with occupational change. Individuals who have a lower school or a secondary school leaving certificate are more likely to drop out than to stop out and start a new VET programme in another occupational field. Women are less likely to stop out with an occupational change. ${ }^{4}$

\section{Stopping out and graduation}

Table 4 shows the regression results for the probability of graduating from the second VET programme. As in the previous analysis, I estimate the three models again (column 2 to column 4). I further estimate these models as selection models with a Heckman correction. I cluster only by training occupation and establishment for the second VET programme (training cells, columns 5 to column 7).

Table 4 shows a negative but not necessarily significant correlation between the timing of termination and success in the subsequent VET programme. A later termination significantly decreases the likelihood of succeeding in the subsequent VET programme. This effect is significant in all models. In the models with the Heckman correction, individuals who terminate in the last year also have a significantly lower likelihood of succeeding in the second VET programme. Starting the subsequent VET programme in another occupational field reduces the likelihood of success by approximately 20 percentage points. The effect remains robust across all models. The matching indicator, which captures changes in training conditions, is significant. Stopouts who change to

\footnotetext{
${ }^{3}$ This relation can also be seen in a logit model, which estimates the probability of occupational change. The later the early termination occurs, the less likely is the starting of an VET in another training occupation (see Table 6in Appendix).

${ }^{4}$ Regression with interactions between gender and occupations do not show any significant effects.
} 


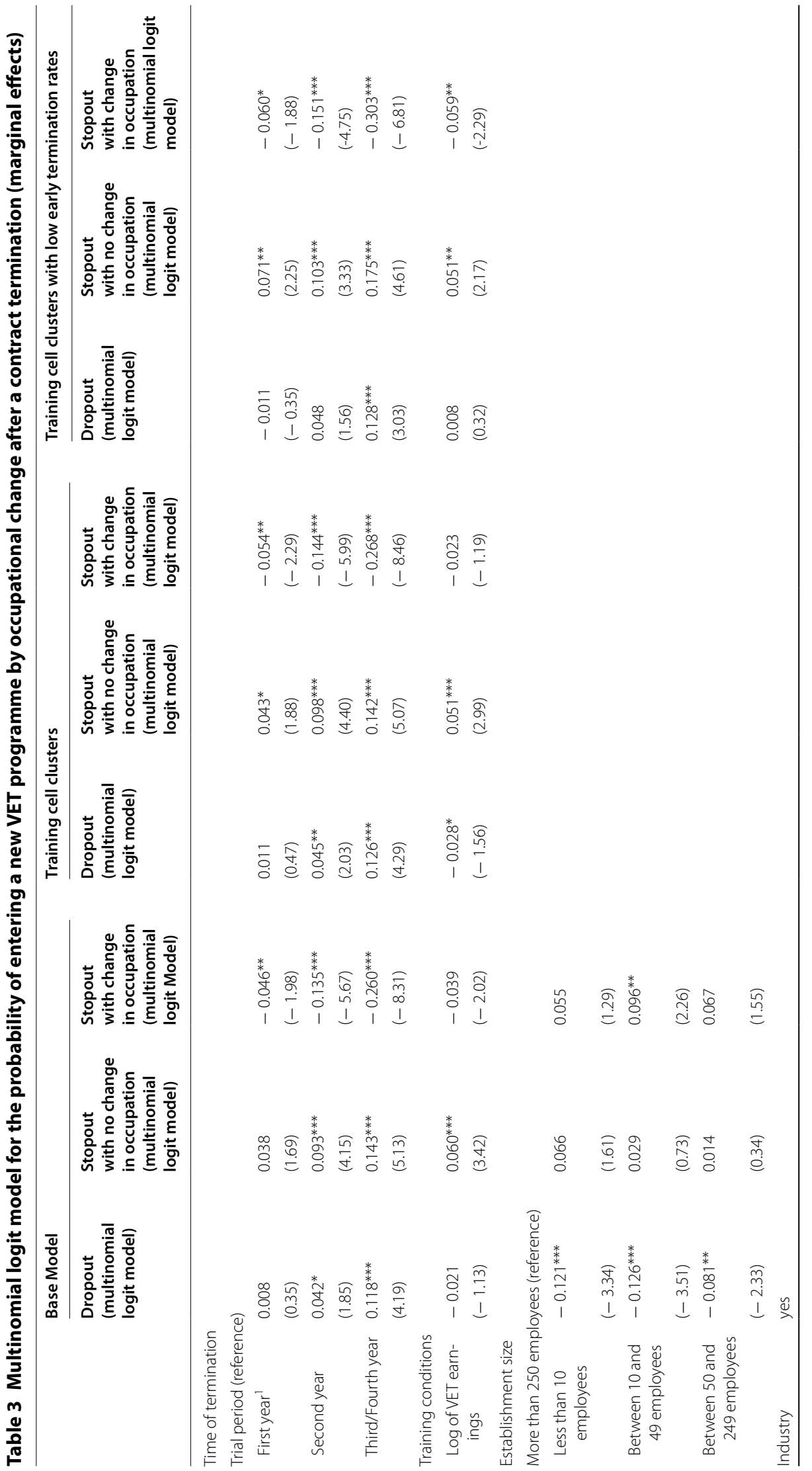




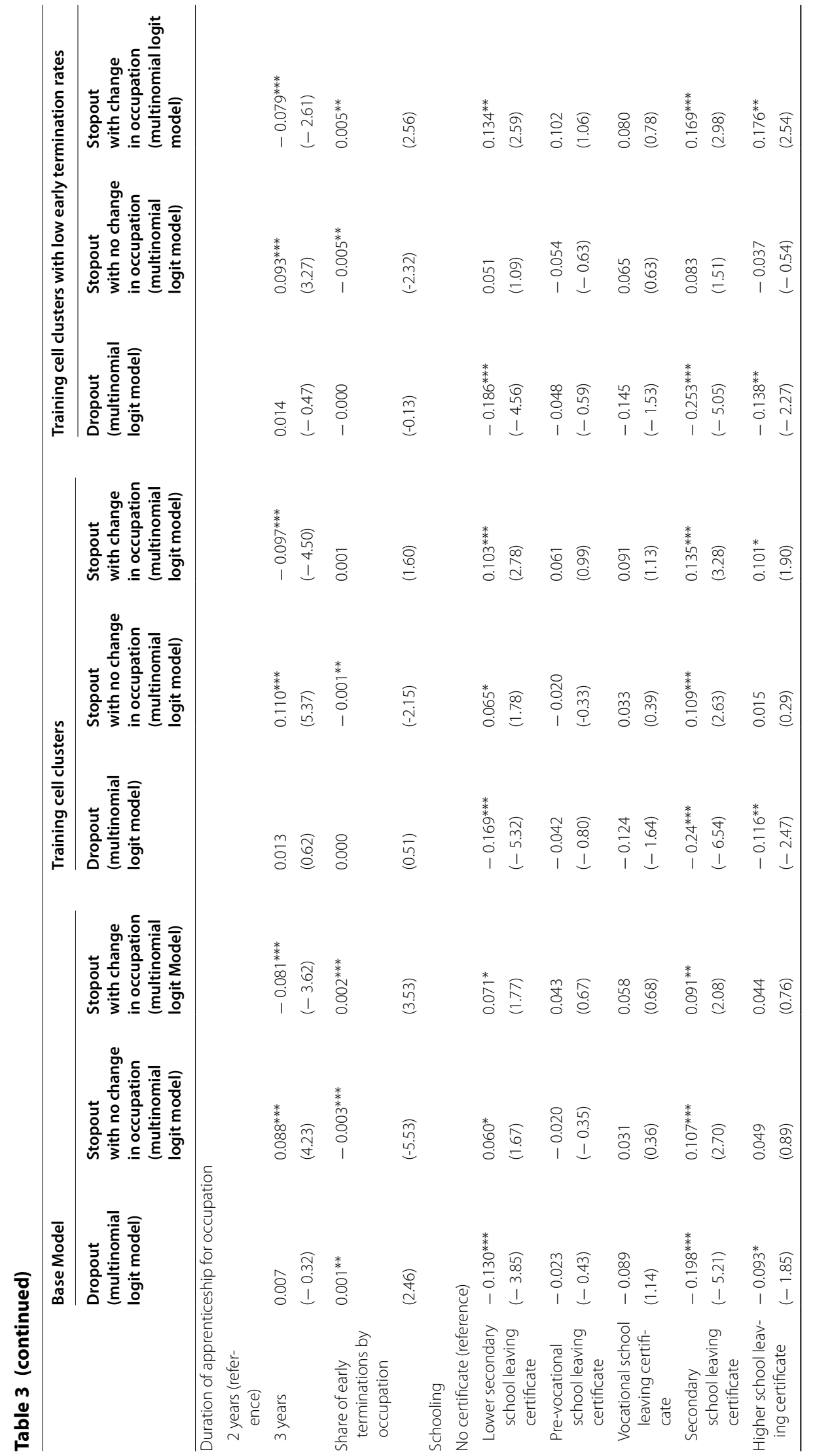




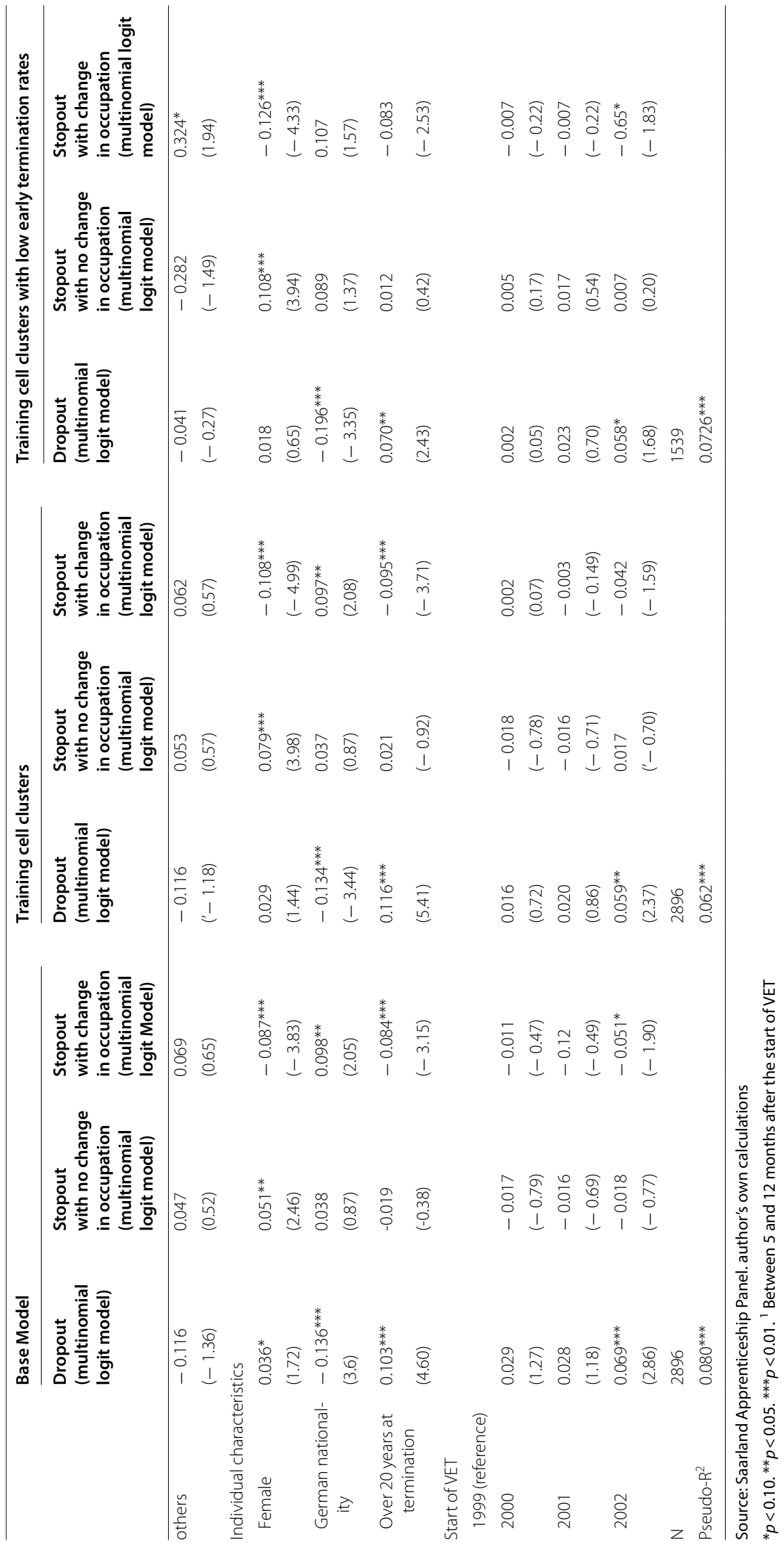


Table 4 Logit model for the probability of succeeding in the second VET programme (marginal effects)

\begin{tabular}{|c|c|c|c|c|c|c|}
\hline & \multicolumn{3}{|l|}{ Logit-model } & \multicolumn{3}{|c|}{ Logit-model with Heckman correction } \\
\hline & Base model & $\begin{array}{l}\text { With training } \\
\text { cell clusters }\end{array}$ & $\begin{array}{l}\text { Training } \\
\text { cell clusters } \\
\text { with low early } \\
\text { termination } \\
\text { rates }\end{array}$ & Base model & $\begin{array}{l}\text { With training } \\
\text { cell clusters }\end{array}$ & $\begin{array}{l}\text { Training } \\
\text { cell clusters } \\
\text { with low early } \\
\text { termination } \\
\text { rates }\end{array}$ \\
\hline \multicolumn{7}{|c|}{ Time of termination } \\
\hline \multicolumn{7}{|c|}{ Trial period (reference) } \\
\hline First year ${ }^{1}$ & $\begin{array}{l}-0.002 \\
(-0.05)\end{array}$ & $\begin{array}{l}-0.003 \\
(-0.11)\end{array}$ & $\begin{array}{l}-0.063 \\
(-1.63)\end{array}$ & $\begin{array}{l}-0.005 \\
(-0.20)\end{array}$ & $\begin{array}{l}-0.007 \\
(-0.26)\end{array}$ & $\begin{array}{l}-0.067^{*} \\
(-1.72)\end{array}$ \\
\hline Second year & $\begin{array}{l}-0.051^{*} \\
(-1.72)\end{array}$ & $\begin{array}{l}-0.049 \\
(-1.65)\end{array}$ & $\begin{array}{l}-0.055 \\
(-1.28)\end{array}$ & $\begin{array}{l}-0.045 \\
(-1.49)\end{array}$ & $\begin{array}{l}-0.040 \\
(-1.36)\end{array}$ & $\begin{array}{l}-0.042 \\
(-0.97)\end{array}$ \\
\hline $\begin{array}{l}\text { Third/Fourth } \\
\text { year }\end{array}$ & $\begin{array}{l}-0.192^{* * *} \\
(-4.70)\end{array}$ & $\begin{array}{l}-0.181^{* * *} \\
(-4.35)\end{array}$ & $\begin{array}{l}-0.185^{* * *} \\
(-3.14)\end{array}$ & $\begin{array}{l}-0.191^{* * *} \\
(-4.75)\end{array}$ & $\begin{array}{l}-0.184^{* * *} \\
(-4.42)\end{array}$ & $\begin{array}{l}-0.179^{* * *} \\
(-3.09)\end{array}$ \\
\hline $\begin{array}{l}\text { Change in occu- } \\
\text { pation }\end{array}$ & $\begin{array}{l}-0.194^{* * *} \\
(-7.86)\end{array}$ & $\begin{array}{l}-0.200^{* * *} \\
(-8.36)\end{array}$ & $\begin{array}{l}-0.211^{* * *} \\
(-6.37)\end{array}$ & $\begin{array}{l}-0.194^{* * *} \\
(-7.77)\end{array}$ & $\begin{array}{l}-0.198^{* * *} \\
(-8.18)\end{array}$ & $\begin{array}{l}-0.212^{* * *} \\
(-6.47)\end{array}$ \\
\hline \multicolumn{7}{|c|}{$\begin{array}{l}\text { Change in } \\
\text { larger estab- } \\
\text { lishment } \\
\text { with higher } \\
\text { wages (refer- } \\
\text { ence) }\end{array}$} \\
\hline $\begin{array}{l}\text { Change in } \\
\text { smaller } \\
\text { establish- } \\
\text { ment with } \\
\text { lower wages }\end{array}$ & $\begin{array}{l}-0.072^{*} \\
(-1.87)\end{array}$ & $\begin{array}{l}-0.097^{* * *} \\
(-2.63)\end{array}$ & $\begin{array}{l}-0.113^{* *} \\
(-2.31)\end{array}$ & $\begin{array}{l}-0.044 \\
(-1.12)\end{array}$ & $\begin{array}{l}-0.077^{* *} \\
(-2.07)\end{array}$ & $\begin{array}{l}-0.098^{* *} \\
(-2.01)\end{array}$ \\
\hline $\begin{array}{l}\text { Change in } \\
\text { larger estab- } \\
\text { lishment } \\
\text { with lower } \\
\text { wages }\end{array}$ & $\begin{array}{l}-0.074^{* *} \\
(-2.39)\end{array}$ & $\begin{array}{l}-0.074^{* *} \\
(-2.50)\end{array}$ & $\begin{array}{l}-0.021 \\
(-0.52)\end{array}$ & $\begin{array}{l}-0.065^{* *} \\
(-2.08)\end{array}$ & $\begin{array}{l}-0.064^{* *} \\
(-2.17)\end{array}$ & $\begin{array}{l}-0.014 \\
(-0.35)\end{array}$ \\
\hline $\begin{array}{l}\text { Change in } \\
\text { smaller } \\
\text { establish- } \\
\text { ment with } \\
\text { higher wages }\end{array}$ & $\begin{array}{l}\prime-0.059^{*} \\
(-1.80)\end{array}$ & $\begin{array}{l}-0.067^{* *} \\
(-2.21)\end{array}$ & $\begin{array}{l}-0.011 \\
(-0.25)\end{array}$ & $\begin{array}{l}-0.041 \\
(-1.20)\end{array}$ & $\begin{array}{l}-0.057^{*} \\
(-1.81)\end{array}$ & $\begin{array}{l}0.001 \\
(0.02)\end{array}$ \\
\hline $\begin{array}{l}\text { Log of VET earn- } \\
\text { ings }\end{array}$ & $\begin{array}{l}0.024 \\
(1.09)\end{array}$ & $\begin{array}{l}0.035 \\
(1.53)\end{array}$ & $\begin{array}{l}0.018 \\
(0.54)\end{array}$ & & & \\
\hline \multicolumn{7}{|c|}{ Training conditions (2nd VET) } \\
\hline \multicolumn{7}{|l|}{$\begin{array}{c}\text { More than } 250 \\
\text { employees } \\
\text { (reference) }\end{array}$} \\
\hline $\begin{array}{l}\text { Less than } 10 \\
\text { employees }\end{array}$ & $\begin{array}{l}0.036 \\
(-0.81)\end{array}$ & & & $\begin{array}{l}0.060 \\
(-1.33)\end{array}$ & & \\
\hline $\begin{array}{l}\text { Between } 10 \\
\text { and } 49 \\
\text { employees }\end{array}$ & $\begin{array}{l}0.045 \\
(-1.04)\end{array}$ & & & $\begin{array}{l}0.066 \\
(-1.50)\end{array}$ & & \\
\hline $\begin{array}{l}\text { Between } 50 \\
\text { and } 249 \\
\text { employees }\end{array}$ & $\begin{array}{l}0.007 \\
(0.15)\end{array}$ & & & $\begin{array}{l}-0.005 \\
(-0.12)\end{array}$ & & \\
\hline Economic sector & Yes & & & & & \\
\hline $\begin{array}{l}\text { Occupation at } \\
\text { the 1-digit } \\
\text { level }\end{array}$ & Yes & & & Yes & & \\
\hline
\end{tabular}


Table 4 (continued)

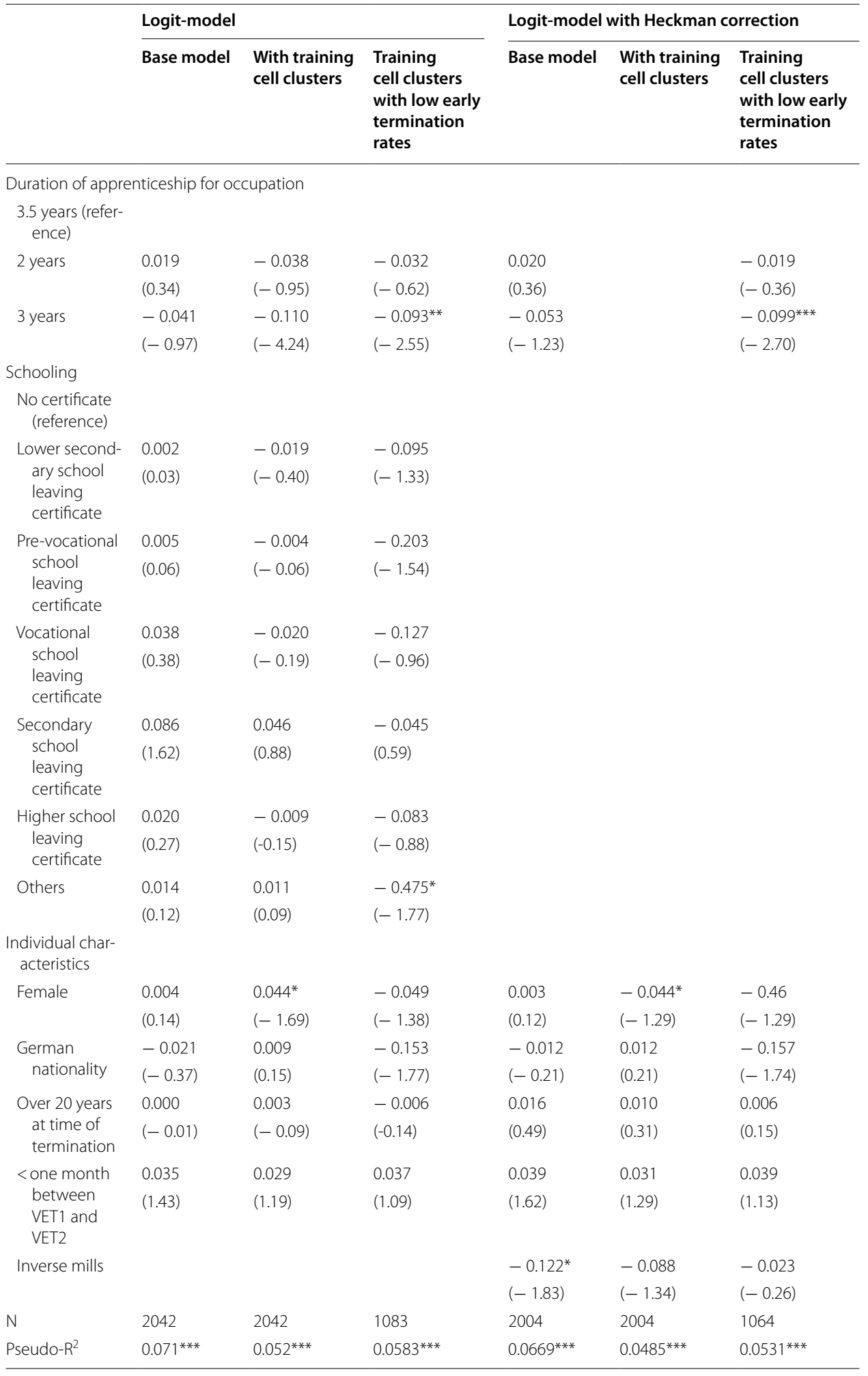

Source: Saarland Apprenticeship Panel. author's own calculations

${ }^{*} p<0.10 .{ }^{* *} p<0.05 .{ }^{* * *} p<0.01$. ${ }^{1}$ Between 5 and 12 months after the start of VET 
smaller establishments, regardless of whether the wage is higher or lower in the new training establishment than in the former establishment, have a significantly lower likelihood of graduating from the second VET programme. The likelihood is also lower for those who change to a larger establishment at a lower wage than for those who start their new training in a larger establishment at a higher wage. School attainment does not significantly affect the likelihood of succeeding in the second VET programme.

\section{Discussion}

The results show that early termination at a later stage of training increases the likelihood of dropping out. Persons who make this termination decision at an early stage instead become stopouts (Bessey and Backes-Gellner 2008). This might be due to an inappropriate match between the training conditions in the training firm, or the contents of the training occupation, and the apprentices. The earlier the termination is, the less knowledge the trainees gain; indeed, the less apprentices have invested into their training, the lower the (opportunity) cost of starting another VET programme is. By contrast, when termination occurs at a later stage, more investments have been made and more knowledge has been gained because the decision to terminate is made during a long-lasting process related to a decline in motivation and in human capital investment (Rumberger and Rotemund 2012; Hodgson 2007). Dropping out can reduce the costs of termination, as the sum of costs and the returns to unskilled work may outweigh the short-term sum of investments and returns to a second VET programme.

The timing of early termination can approximate the amount of human capital investment in a meaningful way (Oreopoulos and Salvanes 2011). To close the information gap with respect to the size of investments, I distinguish between starting VET in a different occupation or in the same occupation. Starting VET in another occupation involves a higher cost than starting VET in the same occupation. This is because the knowledge acquired during the initial VET is forfeited. The later the termination occurs, the higher are the investments in human capital and the more occupation-specific human capital has been acquired, while the costs of starting VET in the same occupation are correspondingly lower, as knowledge can be transferred as well as examinations that are already taken can be credited. Then, investments in a subsequent VET programme are lower for later stages of termination. Furthermore, individuals maintain their chances of obtaining a formal VET degree. Finally, for trainees starting in a new VET field, the likelihood of successful completion is lower than that of trainees starting in the same VET field. In summary, the lower chances of succeeding after a late early termination are due to personal traits rather than to an apprentice-employer mismatch.

Further, training conditions significantly affect the likelihood of success in a subsequent VET programme, particularly as defined by firm size and wage level. This observation, together with an observation of termination at an early stage of training, may be an indicator of matching problems (Bessey and Backes-Gellner 2008) instead of an individual's lack of abilities (Volodina et al. 2015). This should increase the likelihood of graduating from the second VET programme. The effect of changes in training conditions suggests that stopouts who find better training conditions in terms of large training establishments and higher wages are more likely to graduate. The matching indicator used, however, cannot capture personal expectations, as 
expectations depend not only on the content of training in another occupation or in an establishment with higher prestige but also simply on finding an occupation that matches the student's talent or offers better training conditions in terms of the social dimensions.

The results show that the likelihood of stopouts remaining in the same occupation after termination and then succeeding is higher if the returns to training in terms of above-average wages are higher. Such returns offset the required human capital investments. This is in line with the result that late termination of a VET programme with high wages leads a stopout to be more likely to pursue a subsequent VET programme in the same occupation. This indicator captures the additional pay that establishments offer and that might indicate a certain incentive among such establishments to retain apprentices (Mohrenweiser et al. 2020) and therefore give them opportunities to graduate. The indicator value shows that persons who earn above-average wages have advantageous training conditions that lead to graduation. Here, termination may rather stem from a mismatch between the apprentice and the establishment. Furthermore, above-average wages paid by the training firm indicate a certain level of ability as well as motivation among apprentices. This attribute increases the likelihood of obtaining a VET degree and securing a job in a competitive labour market or even improving employability.

The VET programme in Germany gives every school leaver (with or without any school leaving certificate) a chance to obtain a post-secondary vocational degree. School leavers with fewer skills might have fewer opportunities to train in their desired occupation than those with higher skills (e.g., Protsch and Dieckhoff 2011) because employers choose their apprentices via an application process. Therefore, employers select school leavers who best fit their requirements. A higher school leaving certificate would therefore meet such requirements better. However, there is a high share of dropouts with higher school-leaving certificates because of the wider range of educational possibilities open to such students, for example, pursuing higher education at a tertiary institution. Distinguishing the reason for termination requires considering potential endogeneity. Apprentices with higher qualifications who were not able to start VET in their desired occupation may terminate VET if they continue to apply for the desired training occupation and obtain another position at a later stage. Additionally, school leavers with a higher school leaving certificate who cannot start their university studies because the number of places is limited may terminate their contracts when they gain access to university studies. Obtaining a more desirable training position and not the present training position itself causes the termination. In that case, the termination decision is independent of entering a new VET programme. The results (see Table 7) are robust to estimating the models without persons with higher secondary school leaving certificates.

Although the timing of early termination is one of the crucial factors determining whether an apprentice continues and successfully completes a new VET placement, it does not identify different kinds of training investments, as within a given training time, each individual makes different investments. Nor is it possible to distinguish between the investments made by individuals or by the firm. Furthermore, training conditions also reflect firm-specific investments and frameworks, e.g., employers' time spent in training and networks for apprentices within the training firms, which cannot be included in the analysis due to missing information in the data. 


\section{Conclusion}

The analysis has shown that drawing a distinction between dropouts and stopouts after VET termination is necessary. Approximately 70.5 percent of apprentices who terminate their initial training begin another training programme and thus remain in the educational system. Moreover, more than half of these stopouts graduate from their subsequent VET programmes. Remaining in the same occupational field further increases the likelihood of completing their subsequent VET successfully. However, 46 percent of stopouts are dropouts by the end of our observation period, since they have not finished their second attempt at VET. Taking this number in relation to the size of the first VET starting cohort, 11 percent are dropouts. Our results show that the timing of contract termination mainly affects the likelihood of dropping out. The later the contract termination, the more likely a person is to drop out. Likewise, late contract termination in the case of stopping out negatively affects the probability of successfully completing the second VET programme.

These results suggest that it is necessary to recognize the intention to drop out of VET at an early stage of training. Therefore, two strategies can help trainees obtain a VET degree. First, identifying young people with a high dropout risk may reduce that dropout risk. The focus should lie in providing supplementary training support for the establishment or the school and additional teaching staff who can provide intensive support and additional lessons for apprentices to increase their incentives to continue in the VET programme. Second, if the match is not appropriate, it is necessary to make it likely that young adults re-enter VET with an appropriate match in terms of their interests, aspirations and abilities. When a contract is terminated at an early stage of training, the knowledge gained (nonmonetary returns) that may not be valued in the new VET position is small. Therefore, when the decision to terminate a contract occurs earlier, more suitable training conditions are more likely to be successfully found.

Future research should therefore focus on the process of deciding to terminate early and on identifying measures that increase the chances of successfully terminating a VET. Moreover, the question arises as to whether the factors influencing the dropout-stopout decision remain the same over time or during different economic cycles.

Acknowledgements

I would like to thank Stefan Fuchs, Silke Hamann, Holger Seibert and Anne Otto for their helpful comments.

Authors' contributions

The article is written under sole authorship of Gabriele Wydra-Somaggio. The author read and approved the final manuscript.

Funding

The project is not funded.

Availability of data and materials

Please contact the author for further details on the data set.

Competing interests

The author declares that there is no competing interests.

\section{Appendix}

See Tables 5, 6, 7 and Fig. 1. 
Table 5 Sample selection

\begin{tabular}{|c|c|c|c|c|c|c|}
\hline \multirow[t]{2}{*}{ Cleaning steps } & \multicolumn{2}{|c|}{ Chamber of Crafts } & \multicolumn{2}{|c|}{$\begin{array}{l}\text { Chamber of Industry } \\
\text { and Commerce }\end{array}$} & \multicolumn{2}{|l|}{ Overall } \\
\hline & Beginnings & Terminations & Beginnings & Terminations & Beginnings & Terminations \\
\hline $\begin{array}{l}\text { Began between } 1994 \\
\text { and } 2006\end{array}$ & 17,702 & 6704 & 40,001 & 7796 & 57,703 & 14,500 \\
\hline $\begin{array}{l}\text { Apprentice without } \\
\text { prior appren- } \\
\text { ticeship (first } \\
\text { apprenticeship in } \\
\text { chamber) }\end{array}$ & 14,189 & 5215 & 27,435 & 4847 & 41,624 & 10,062 \\
\hline $\begin{array}{l}\text { Apprenticeship start } \\
\text { date in cham- } \\
\text { ber = Apprentice- } \\
\text { ship start date } \\
\text { in IEB }\end{array}$ & 12,606 & 4397 & 24,931 & 4092 & 37,537 & 8489 \\
\hline $\begin{array}{l}\text { Apprenticeship not } \\
\text { funded }\end{array}$ & 12,396 & 4302 & 24,609 & 4017 & 37,005 & 8319 \\
\hline $\begin{array}{l}\text { Apprentice }<23 \text { years } \\
\text { of age }\end{array}$ & 12,204 & 4242 & 23,812 & 3889 & 36,016 & 8131 \\
\hline $\begin{array}{l}\text { Apprenticeship end } \\
\text { date in cham- } \\
\text { ber = Apprentice- } \\
\text { ship end date in IEB }\end{array}$ & & 3739 & & 3105 & & 6844 \\
\hline $\begin{array}{l}\text { Apprenticeship } \\
\text { only in one of the } \\
\text { chambers }\end{array}$ & & & & & & 6791 \\
\hline $\begin{array}{l}\text { Premature con- } \\
\text { tract termination } \\
\text { between } 1999 \text { and } \\
2002 \text { without miss- } \\
\text { ing data }\end{array}$ & & & & & & 2896 \\
\hline
\end{tabular}

Source: Saarland Apprenticeship Panel. author's own calculations

Table 6 Logit model for the probability of changing occupation by timing of termination only stopouts (marginal effects)

\begin{tabular}{lll}
\hline & $\begin{array}{l}\text { With training } \\
\text { cell clustered }\end{array}$ & $\begin{array}{l}\text { With training cell clustered and training } \\
\text { occupation with less than } 50 \% \text { early } \\
\text { termination rate }\end{array}$ \\
\hline Time of premature apprenticeship contract termination & \\
Trial period (reference) & $-0.055^{* *}$ & $-0.079^{* *}$ \\
First year of apprenticeship & $(-1.99)$ & $(-2.08)$ \\
Second year of apprenticeship & $-0.151^{* * *}$ & $-0.1684^{* * *}$ \\
& $(-5.42)$ & $(-4.36)$ \\
Third/Fourth year of apprenticeship & $-0.266^{* * *}$ & $-0.323^{* * *}$ \\
& $(-7.45)$ & $(-6.57)$ \\
Log of VET earnings & $-0.072^{* * *}$ & $-0.099^{* * *}$ \\
& $(-3.27)$ & $(-3.22)$ \\
N & 2043 & 1084 \\
Pseudo R2 & $0.0954^{* * *}$ & $0.1219^{* * *}$ \\
\hline
\end{tabular}

Source: Saarland Apprenticeship Panel. Author's own calculations

Further control variables are age at termination. Establishment size. Economic sector. Occupation, schooling, gender, German nationality and the start of the apprenticeship. The detailed results are available upon request ${ }^{*} p<0.10 .{ }^{* *} p<0.05 .{ }^{* * *} p<0.01 .{ }^{1}$

Between 5 and 12 months after the start of VET 


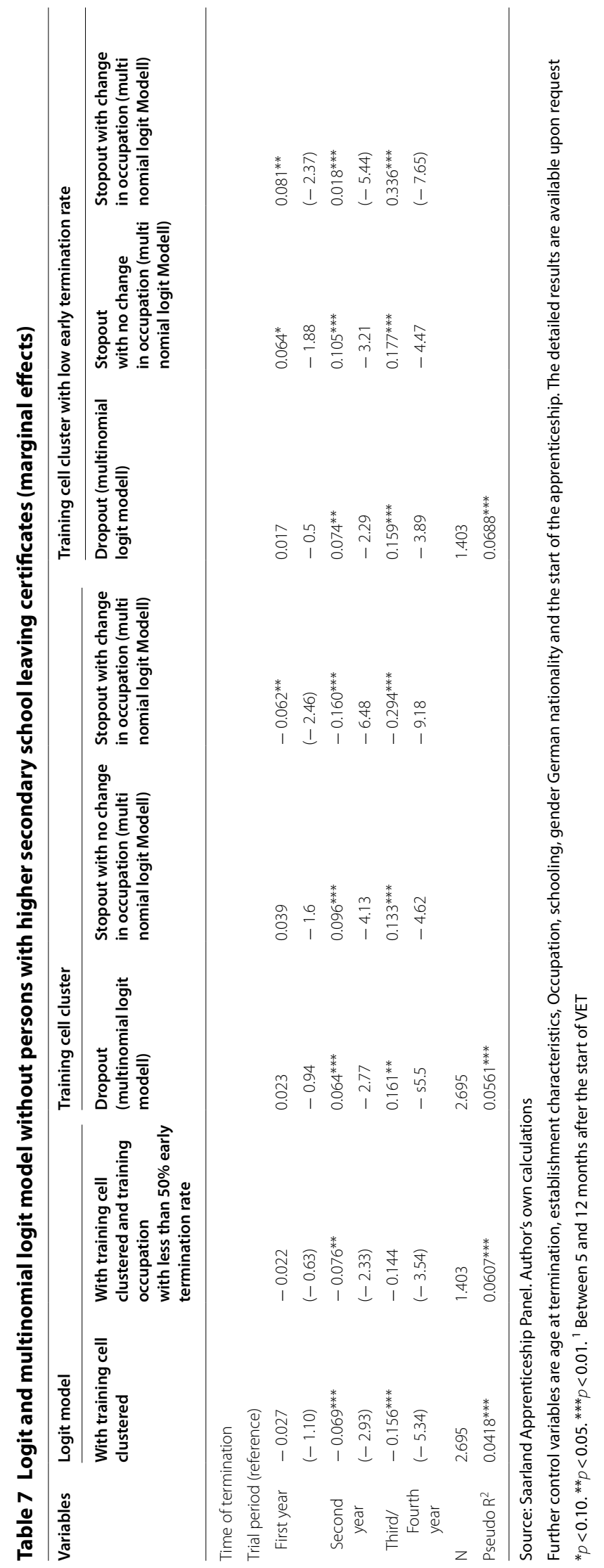


Received: 27 July 2020 Accepted: 20 January 2021

Published online: 11 February 2021

\section{References}

Aarkrog V, Wahlgren B, Larsen CH, Mariager-Anderson K, Gottlieb S (2018) Decision-making processes among potential dropouts in vocational education and training and adult learning. Int J Res Vocational Educ Training (IJRVET) 5(2):111-129

Arulampalam W, Naylor RA, Smith JP (2001) A hazard model of the probability of medical school dropout in the United Kingdom. IZA Discussion Paper No. 333

Becker G (1962) Investment in human capital. A theoretical analysis. In: The Journal of Political Economy, 70(5): 9-49

Bessey D, Backes-Gellner U (2008): Dropping out and revising educational decisions: Evidence from vocational education. Swiss Leading House Working Paper, No 40

BIBB (2020): Datensystem Auszubildende-Datenblätter (DAZUBI), https://www.bibb.de/de/1874.php

Biewen M, Tapalaga M (2017) Life-cycle educational choices in a system with early tracking and 'second chance' options. Econ Educ Rev 56:80-94

Bishop JH, Mane F (2001) The impacts of minimum competency exam graduation requirements on high school graduation, college attendance and early labour market success. Labour Econ 8(2):203-222

Bradley S, Lenton P (2007) Dropping out of post-compulsory education in the UK: an analysis of determinants and outcomes. J Population Econ 20:299-328

Campolieti M, Fang T, Gunderson M (2010) Labour market outcomes and skill acqui-sition of high-school dropouts. J Labor Res 31(1):39-52

Cerda-Navarro A, Sureda-Negre J, Comas-Forgas R (2017) Recommendations for confronting vocational education dropout: a literature review. Empirical Res Vocational Educ Training 9(17):1-23

Coneus K, Gernandt J, Saam M (2011) Noncognitive skills, school achievements and educational dropouts. Schmollers Jahrbuch 131(4):547-568

Eckstein Z, Wolpin KI (1999) Why youth drop out of high school: the impact of preferences, opportunities, and abilities. Econometrica 67(6):1295-1339

Eegdeman I, Meeter M, Van Klaveren C (2018) Cognitive skills, personality traits and dropout in Dutch vocational education. Empirical Res Vocational Educ Training 10(11):1-18

Germeijs V, Verschueren K (2007) High school students' career decision-making process: Consequences for choice implementation in higher education. J Vocat Behav 70:223-241

Gesthuizen M, Solga H (2014) Is the labor market vulnerability of less-educated men really about job competition? New insights from the United States. J Labour Market Res 47(3):205-221

Glaesser J (2006) Dropping out of further education: a fresh start? Findings from a German longitudinal study. J Vocational Educ Training 58(1):83-97

Gubbels J, van der Put CE, Assink M (2019) Risk factors for school absenteeism and dropout: a meta-analytic review. J Youth Adolesc 48:1637-1667

Gury N (2011) Dropping out of higher education in France: a micro-economic approach using survival analysis. Educ Econ 19(1):51-64

Hodgson D (2007) Towards a more telling way of understanding early school leaving. Issues Educ Res 17(1):40-61

Karmel T, Mlotkowski P (2010): How reasons for not completing apprenticeship and traineeship change with duration. Occasional Paper of National Center for Vocational Education Research (NCVER), Adelaide

Kearney MS, Levine PB (2014): Income inequality, social mobility, and the decision to drop out of high school. NBER Working Paper No. 20195

Kotte V (2018) Durchläufer" und "Drop-Outs" * (Dis-) Kontinuitäten von Ausbildungsverläufen im dualen System. Zeitschrift für Pädagogik 64(4):441-460

Laporte C, Mueller R (2013) The completion behaviour of registered apprentices in Canada: who continues, who quits, and who completes programs? Emprical Res Vocational Educ Training 5(1):1-30

Lassibille G, Navarro Gomez L (2008) Why do higher education students drop out? Evid Spain Educ Econ 16(1):89-105

Mangan J, Trendle B (2008) Surviving apprenticeship training: a duration analysis of apprenticeship contracts in Australia. J Interdisciplinary Econ 19:379-398

Manski CF (1989) Schooling as experimentation: a reappraisal of the postsecondary dropout phenomenon. Econ Educ Rev 8(4):305-312

Mohrenweiser J, Wydra-Somaggio G, Zwick T (2020) Information advantages of training employers despite credible training certificates. Oxford Econ Papers 73(3):651-671

Montmarquette C, Mahseredjian S, Houle R (2001) The determinants of university dropouts: a bivariate probability model with sample selection. Econ Educ Rev 20:475-484

Oberschachtsiek D, Scioch P, Seysen C, Heining J (2009) Stichprobe der Integrierten Erwerbsbiografien IEBS. Handbuch für die IEBS in der Fassung 2008. (= FDZ Datenreport No. 03/2009), Nuremberg

Oreopoulos P (2007) Do dropouts drop out too soon? Wealth, health and happiness from compulsory schooling. J Public Econ 91:2213-2229

Oreopoulos P, Salvanes KG (2011) Priceless: the nonpecuniary benefits of schooling. J Econ Perspectives 25(1):159-184

Patzina A, Wydra-Somaggio G (2020) Early careers of dropouts from vocational training * signals, human capital formation, and training firms. Eur Sociol Rev 36(5):741-759

Protsch P, Dieckhoff M (2011) Educational credentials, cognitive abilities or personality? Eur Soc 13:69-91

Rohrbach-Schmidt D, Uhly A (2015) Determinanten vorzeitiger Lösungen von Ausbildungsverträgen und berufliche Segmentierung im dualen System. Eine Mehrebenenanalyse auf Basis der Berufsbildungsstatistik. Kölner Zeitschrift Soziologie Sozialpsychologie 67:105-135 
Rumberger RW, Lamb SP (2003) The early employment and further education experiences of high school dropouts: a comparative study of the United States and Australia. Econ Educ Rev 22:353-366

Rumberger RW, Rotermund S (2012) The relationship between engagement and high school dropout. In: Christenson SL, Reschly AL, Wylie C (eds) Handbook of research on student engagement. Springer, Boston

Snell D, Hart A (2008) Reasons for non-completion and dissatisfaction among apprentices and trainees: a regional case study. Int J Training Res 6(1):44-73

Stratton LS, O'Toole DM, Wetzel JN (2008) A multinomial logitmodel of college stopout and dropout behaviour. Econ Educ Rev 27:319-331

Volodina A, Nagy G, Köller O (2015) Success in the first phase of the vocational career: The role of cognitive and scholastic abilities, personality factors, and vocational interests. J Vocational Behav 91(1):11-22

Wydra-Somaggio G (2015) Das Ausbildungspanel Saarland. Dokumentation der Datenaufbereitung. IAB-Regional. Berichte und Analysen aus dem Regionalen Forschungsnetz. IAB Rheinland-Pfalz-Saarland, 03/2015, Nuremberg

\section{Publisher's Note}

Springer Nature remains neutral with regard to jurisdictional claims in published maps and institutional affiliations.

\section{Submit your manuscript to a SpringerOpen ${ }^{\circ}$ journal and benefit from:}

- Convenient online submission

- Rigorous peer review

- Open access: articles freely available online

- High visibility within the field

- Retaining the copyright to your article

Submit your next manuscript at $\gg$ springeropen.com 